\title{
PENERAPAN PENERAPAN SISTEM INFORMASI MANAJEMEN DALAM MANAJEMEN SEKOLAH ATAU PERGURUAN TINGGI
}

\author{
Frans Adetya Harahap \\ Prodi Sistem Informasi, Fakultas Sains dan Teknologi, Universitas Islam \\ Negeri Sumatera Utara \\ Email: fransharahap0804@gmail.com
}

\begin{abstract}
ABSTRAK
Penerapan sistem informasi manajemen dalam manajemen sekolah atau perguruan tinggi sangat memiliki pengaruh dan peranan penting dalam kegiatan manajemen. Pengelolaan sistem informasi manajemen yang baik akan berpengaruh langsung kepada kinerja dan organisasi dan lembaga pendidikan. Sistem informasi manajemen juga berperan langsung dalam proses pengambilan keputusan di sekolah dan perguruan tinggi karena data dan informasi yang didapat akan membantu manajer ataupun kepala sekolah dalam menentukan tindakan dalam pengambilan keputusan. Selain itu, penerapan sistem informasi manajemen yang baik dan tepat akan mempermudah dan mempercepat suatu pekerjaan.
\end{abstract}

\section{Kata kunci: Penerapan, Peran, Sistem Informasi , Pengambilan Keputusan, Manajemen.}

\begin{abstract}
The application of Management Information Systems in school or college management has an important influence and role in management activities. Good management of Management Information Systems will have a direct effect on performance and educational organizations and institutions. Management Information Systems also play a direct role in the decisionmaking process in schools and colleges because the data and information obtained will help managers or principals in determining actions in decision making.
\end{abstract}

Keywords: Implementation, Role, Information Systems, Decision Making, Management.

\section{A. Pendahuluan \\ Latar Belakang Masalah}

Dilihat dari perkembangan zaman sekarang, semakin hari teknologi dan pengetahuan semakin berkembang pesat. Tidak dapat dipungkiri bahwa untuk mencari dan mendapatkan informasi bisa dari sumber mana saja. Tetapi, semua informasi yang didapatkan tersebut belum tentu benar atau 
salahnya. Kebanyakan pada era sekarang informasi dan berita-berita yang beredar di kalangan masyarakat ada unsur hoax atau disebut juga informasi berita palsu yang hanya dibuat-buat tanpa pertanggungjawaban yang pasti. Dan untuk menyaring informasi berita dan data yang didapat tersebut kita harus memiliki modal terlebih dahulu seperti wawasan yang luas mampu berkomunikasi dengan baik dan juga harus dapat mampu memahami perkembangan ilmu pengetahuan dan teknologi yang ada.

Perkembangan teknologi yang terjadi pada saat ini memiliki banyak dampak bagi penggunanya terutama kita sebagai manusia. Pada saat sekarang setiap orang dalam menguasai sistem informasi yang melakukan kegiatan tidak pernah lepas dari bantuan teknologi. Contohnya sekarang pekerjaan manusia bisa digantikan oleh alatalat teknologi yang canggih. Dan jika dikaitkan dalam bidang pendidikan perkembangan teknologi juga sangat pesat dan berpengaruh terhadap dunia pendidikan. Dapat kita lihat bahwasanya di dalam dunia pendidikan untuk penyajian informasi dan data rata-rata sudah dalam bentuk elektronik. Seperti surat edaran dalam bentuk softcopy dan juga pemberitahuan informasi lainnya di situs-situs web yang ada.

Di dalam manajemen sekolah atau pendidikan pengelolaan sistem informasi nya sudah diseimbangkan dengan perkembangan ilmu pengetahuan yang ada. Seperti untuk menginput data siswa, guru dan tenaga kependidikan di sekolah sudah menggunakan suatu aplikasi sistem informasi manajemen digital yang langsung online ke data dari pemerintahan pusat. Penerapan sistem informasi manajemen dalam dunia pendidikan terutama di sekolah atau perguruan tinggi ratarata sudah baik, namun tinggal lagi kepada penggunanya yang belum ada tersebut. Maka dari itu agar penerapan atau implementasi sistem informasi manajemen baik, efektif dan efisien itu butuh kerja sama dan dukungan dari semua pihak dalam sekolah atau perguruan tinggi yang ada. Dengan memanfaatkan teknologi yang ada implementasi kegiatan sistem informasi dalam manajemen sekolah harus lebih memudahkan segala urusan atau pekerjaan sekolah atau perguruan tinggi tersebut.

\section{Rumusan Masalah}

Berdasarkan latar belakang masalah di atas maka rumusan masalah yang dibahas adalah tentang peranan penerapan sistem informasi manajemen dalam manajemen sekolah dan perguruan tinggi.

\section{Tujuan Penulisan}

Adapun tujuan penulisan artikel ini adalah untuk mengetahui peranan penerapan sistem informasi manajemen dalam manajemen sekolah dan perguruan tinggi selain itu juga untuk mengetahui apakah sistem informasi manajemen tersebut dapat berjalan dengan baik atau tidak. Dan juga untuk mengetahui apakah penerapan Sistem Informasi Manajemen ini 
bermanfaat di berbagai bidang serta manfaat penerapan Sistem Informasi Manajemen di Sekolah ataupun Perguruan Tinggi.

\section{Metode Penelitian}

Dalam penelitian ini penulis melakukan analisa terhadap satu variabel, yaitu variabel penerapan sistem informasi manajemen pendidikan dalam peningkatan pelayanan sekolah kepada masyarakat. Metode yang digunakan dalam penelitian ini adalah deskriptif kuantitatif, untuk menganalisis data menggunakan distribusi frekuensi, frekuensi komulatif, frekuensi mutlak, presentasi, dan pengkategorian. Metode penelitian ini menggunakan metode penelitian kualitatif yakni proses dalam pencatatan yang menggambarkan fakta yang ada berdasarkan keadaan objek yang diteliti (Creswell,2018). Metode ini bersifat interpretif yang ciri-cirinya berdasarkan adanya pendapat karena hasil penelitian lebih berkaitan dengan interpretasi data yang ditemukan di lapangan.

\section{B. Kajian Literatur}

\section{Konsep Dasar Sistem Informasi Manajemen (SIM)}

Menurut Mc.Leod dalam Yakub (2012) dalam (Vindi Agustiandra,2019) mendefinisikan Sistem Informasi Manajemen (SIM) ialah suatu sistem yang menyediakan informasi untuk para pemakainya dengan berbasis komputer. Sedangkan menurut Moeldjojodihardjo dalam sutabri
(2005) dalam (Vindi Agustiandra,2019) Sistem Informasi (SIM) adalah sebuah metode yang digunakan untuk menghasilkan informasi yang tepat dan berguna dalam manajemen di luar organisasi serta dapat menunjang dalam proses pengambilan keputusan, perencanaan dan juga dalam proses pengawasan. Selain itu Hartono (2013) dalam (Vindi Agustiandra,2019) mengungkapkan bahwa Sistem Informasi Manajemen (SIM) ialah sebuah sistem, terdiri dari rangkaian dan komponen-komponen yang saling bekerja sama untuk menghasilkan sebuah informasi yang berguna bagi manajemen di sebuah perusahaan.

Dari beberapa definisi atau pengertian Sistem Informasi Manajemen (SIM) diatas, maka dapat kita simpulkan bahwa Sistem Informasi Manajemen (SIM) adalah sebuah sistem yang terdiri dari berbagai jenis komponenkomponen, elemen-elemen yang saling bekerja sama demi suatu tujuan yaitu menghasilkan sebuah informasi yang berguna untuk membantu pekerjaan dari manajemen perusahaan ataupun organisasi. Sistem Informasi Manajemen (SIM) adalah penerapan sistem informasi di dalam sebuah organisasi untuk mempermudah orang-orang atau bagian-bagian di dalam organisasi tersebut mendapatkan informasi yang dibutuhkan (Liputsari, 2013). Tujuan utama dari Sistem Informasi Manajemen (SIM) ini adalah untuk mempermudah pekerjaan dan 
apalagi yang berhubungan dengan data dan informasi.

Menurut (Lipursari 2013) ada beberapa karakteristik Sistem Informasi Manajemen (SIM) yaitu:

(1) Sistem Informasi Manajemen tersebut bergantung kepada letak data dan alur informasi dalam suatu organisasi.

(2) Sistem Informasi Manajemen berorientasi pada data dan bentuknya tidak fleksibel, tetapi akan membantu manajer atau siapapun dalam organisasi/perusahaan dalam menyelesaikan pekerjaannya dengan cepat dan tepat. Dalam (Dyna Marisa Khairina,2018) ada beberapa tujuan dari Sistem Informasi Manajemen (SIM) yaitu: (1) untuk menyediakan berbagai informasi yang dipergunakan dalam menentukan berbagai hal yang diinginkan organisasi atau manajemen, (2) Untuk menyediakan informasi yang dibutuhkan dan digunakan dalam perencanaan pengendalian, evaluasi, dan perbaikan lanjutan, (3) untuk menyediakan informasi untuk pengambilan keputusan.

Selain itu juga ada beberapa manfaat dalam penerapan Sistem Informasi Manajemen (SIM) yaitu dapat meningkatkan efisiensi dan efektivitas data secara akurat dan tepat waktu, bisa mempermudah pekerjaan manajemen mulai dari perencanaan pelaksanaan pengawasan dan lainnya, juga mampu meningkatkan kualitas sumber daya manusia dan dapat juga untuk meningkatkan produktivitas serta penghematan biaya dalam organisasi.

\section{Sistem Informasi Manajemen Sekolah}

Sistem informasi manajemen sekolah ialah suatu aplikasi sekolah yang menjadi terobosan yang sangat dibutuhkan sekolah di zaman sekarang yang sudah serba maju ini.

Beberapa manfaat sistem informasi:

1. Dapat meningkatkan aksesibilitas data yang tersaji secara tepat waktu dan akurat bagi para pemakai, tanpa mewajibkan adanya perantara sistem informasi.

2. Dapat mengembangkan proses perencanaan dan kegiatan manajemen dengan cara efektif.

3. Efisiensi kebutuhan sekolahsekolah.

4. Penjagaan dan keamanan data terjamin dengan di sistemkannya kegiatan Arsip.

5. Dapat memperbaiki produktivitas dan kinerja di setiap level manajemen.

6. Sekolah dapat menggunakan sistem informasi untuk mengolah transaksi-transaksi mengurangi biaya dan menghasilkan pendapatan sebagai salah satu produk atau pelayanan mereka.

7. Dapat mendukung pengambilan keputusan manajerial.

8. Dapat mendukung tercapainya keunggulan strategis. 
Ada banyak macam serta juga sistem informasi yang beredar di masyarakat, yang sangat populer digunakan adalah sistem informasi manajemen sekolah berbasis web yang dapat dirasa penggunaannya mudah dan tidak memerlukan komputer dengan spesifikasi yang tinggi, di setingkat universitas kita semua dapat mengenal sistem informasi akademik, pada dasarnya sistemnya sama hanya pada level kebutuhannya saja yang berbeda dari yg lain, tetapi titik sejatinya aplikasi berupa sistem informasi sekolah dapat membantu meningkatkan mutu kualitas pelayanan di setiap sekolah dan juga dapat membantu para pengambilpengambil keputusan secara cermat menetapkan kebijakan strategi yang dipergunakan untuk mencapai tujuan dari sekolah.

\section{Sistem Informasi \\ Manajemen Perguruan Tinggi}

Perguruan tinggi sebagai suatu sistem yang sangat besar, memiliki subsistem yang sangat banyak sehingga masing-masing dapat membentuk pola hubungan kerja yang mewujudkan sebuah sentralisasi sistem yang bekerja secara harmonis, bisa saling dukung mendukung dan terkait satu dengan yang lain.

Sistem Informasi Manajemen Perguruan Tinggi diharapkan dapat menjadi salah satu solusi untuk dapat membantu menyelesaikan permasalahan-permasalahan manajemen di setiap tata kelola perguruan tinggi yang ada titik untuk menghasilkan sebuah sistem informasi agar terintegritas dengan sangat baik, perlu diperhatikan tiga hal: Pertama, sistem informasi didefinisikan secara jelas dan lebih terperinci sehubungan dengan jenisjenis informasi apa yang dibutuhkan oleh institusi. Hal-hal yang berkaitan dengan kecepatan proses pengolahan data informasi, tingkatan detail informasi, cara untuk penampilan informasi. Kedua, adanya teknologi infrastruktur, alat komunikasi, dan perangkat lunak (aplikasi, sistem operasi, database, dan lain-lain) yang sangat harus tersedia. Ketiga, adanya manajemen informasi yang menyangkut perangkat manusia atau brainware yang akan mengimplementasikan sistem informasi yang dibangun dan yang akan mengembangkan teknologi informasi.

\section{Karakteristik Sistem Informasi} Manajemen Perguruan Tinggi adalah untuk menjadi sarana pendukung lembaga pendidikan tinggi agar mencapai tujuan untuk memberikan layanan yang diperlukan untuk masyarakat akademis secara memuaskan, andal dan lebih terjangkau, menaikkan mutu pelayanan sesuai dengan misi pendidikan tinggi, dan juga memberikan informasi yang akurat dari luar institusi.

\section{Konsep \\ Dasar Manajemen Sekolah}

Menurut Danum (2010:38) dalam jurnal 9 menjelaskan 
bahwa sekolah merupakan lembaga yang otonom namun dalam penyelenggaraannya ini masih berada di bawah naungan atau bagian dari sistem pendidikan nasional yang dapat ditemui pada manajemen berbasis sekolah (MBS). Minarto (2010:46) dalam (Triwiyanto 2013) menyebutkan bahwa manajemen berbasis sekolah adalah sebuah layanan yang komprehensif dan tanggap terhadap kebutuhan masyarakat. Titik tujuan diadakannya manajemen sekolah atau manajemen pendidikan ini yaitu untuk meningkatkan dan juga untuk mengoptimalkan pekerjaan setiap instansi pendidikan sehingga tujuan pendidikan ini dapat tercapai sesuai yang sudah direncanakan sebelumnya.

\section{Konsep Dasar Manajemen Perguruan Tinggi}

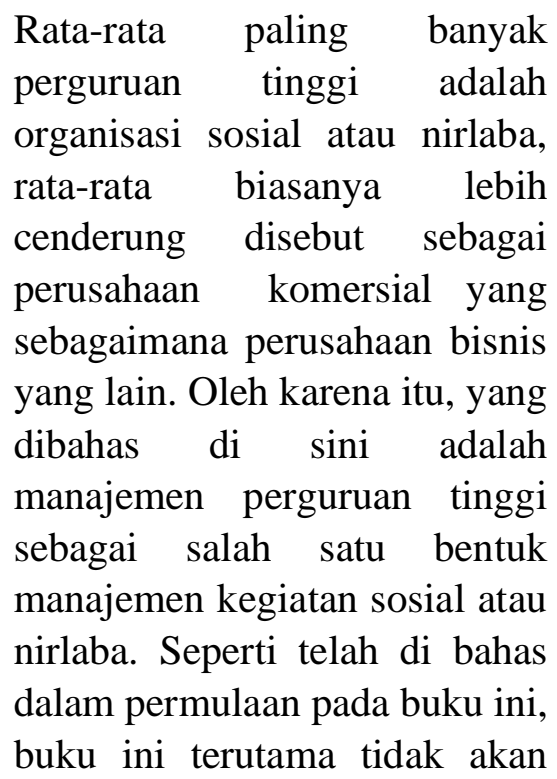

membahas mengenai arah yang harus ditujukan dan untuk menuju mengenai kegiatan utama universitas yaitu kegiatan belajar mengajar penelitian dan pengabdian kepada masyarakat juga bukan mengenai kebijakan nasional mengenai pendidikan dan sebab menguntungkan. Demikian juga buku ini bukan merupakan baru atau panduan kegiatan administrasi yang baik dalam suatu universitas bahasan utama yang akan disajikan adalah mengenai proses dan aktivitas manajemen yang perlu dilakukan dengan pokok-pokok bahasan mengenai manajemen strategis dan cara pengukuran percaya kinerja manajemen. Kalau hal-hal di atas yaitu kegiatan belajar mengajar sistem pendidikan nasional dan juga kegiatan administrasif yang dibicarakan, saya hanya bisa sekedar menjelaskan contoh dalam kegiatan atau latar belakang pembahasan ini bukan merupakan titik sentral pembahasan titik kecuali beberapa dimensi makna atau fungsi yang termasuk hakikat dari universitas, makna korporasi pun masih mempunyai subdimensi pengertian lagi titik korporasi universitas dapat dipandang pula sebagai suatu lembaga, suatu perusahaan, dan suatu agen atau perantara.

\section{Pengaruh Sistem Informasi Manajemen dalam Manajemen Sekolah atau Perguruan Tinggi}


Pengaruh Sistem Informasi Manajemen dalam manajemen sekolah atau perguruan tinggi sangat mempengaruhi tingkat kualitas pendidikan yang ada di Indonesia. Peran sistem informasi dan teknologi sangat menentukan keberhasilan pendidikan di Indonesia saat ini, titik proses yang unggul harus juga didukung oleh sistem dan alat yang dapat memberikan pedoman dan informasi yang lebih tepat serta pengelolaan yang sangat baik. Informasi dan proses tersebut juga didukung oleh teknologi informasi yang sesuai dan tepat sehingga dapat dijadikan sebagai dasar bagi manajer dan pengambilan keputusan dan dasar untuk tercapainya tujuan pendidikan.

\section{C.Pembahasan}

Sistem informasi manajemen yang dikemukakan oleh Susanto (Susanto,2002) merupakan integritas dari beberapa komponenkomponen yang mendukung yaitu seperti hardware, software, brainware, prosedur, database dan teknologi komunikasi yang berfungsi sebagai alat untuk mengolah-mengolah data yang berasal dari berbagai sumber untuk di informasikan kepada pihak berbagai tingkatan dan bagian manajemen.

Menurut Ahmad sabandi (Sabandi,Ahmad. Dewi Putri,2019) Sistem Informasi Manajemen adalah suatu metode untuk dapat bisa menghasilkan informasi yang tepat waktu bagi manajemen tentang lingkungan luar organisasi Untuk bermaksud tujuan untuk menunjang proses pengambilan keputusan serta juga untuk memperbaiki proses perencanaan dan pengawasan. Dengan karena itu dengan adanya sistem informasi di sekolah-sekolah mampu mempermudah guru untuk menghasilkan mutu pendidikan yang lebih berkualitas. Pemerintah dan Kemendikbud sudah melakukan upaya yang sangat besar untuk memenuhi kebutuhan teknologi yang ada dalam dunia pendidikan Indonesia. Pemanfaatan ilmu pengetahuan dan teknologi yang semakin berkembang dapat meningkatkan kualitas pembelajaran sehingga akan berpengaruh terhadap peningkatan kualitas pendidikan yang ada di Indonesia.

Penerapan Sistem Informasi Manajemen (SIM) dalam manajemen sekolah atau perguruan tinggi itu biasanya di bagian akademik, atau disebut juga dengan istilah Sistem Informasi Manajemen Akademik. Dimana kata akademik itu sendiri berarti ke seluruh lembaga pendidikan formal mulai dari pendidikan anak usia dini sama pendidikan tinggi yang melaksanakan pendidikan vokasi mulai dari cabang pengetahuan keterampilan dan seni tertentu. Maka dapat dikatakan bahwa sistem informasi manajemen akademik adalah berbagai macam bentuk interaksi yang dilakukan antara komponen atau elemen-elemen di lingkungan akademik atau pendidikan yang akan memberikan informasi dan membantu dalam 
pengambilan keputusan ( Vindi Agustiandra,2019).

Berdasarkan entitas dan propertiesnya dalam (Indrayani 2011) sistem informasi akademik merujuk pada seperangkat sistem dan juga aktivitas yang digunakan untuk menata, memproses, dan menggunakan informasi sebagai sumber dalam organisasi (Sprange \& Carloson,1982). Sedangkan menurut (Shiddiq \& Pradyna,2013) sistem informasi akademik adalah suatu sistem yang dapat mengolah semua aktivitas yang berkaitan dengan akademis seperti kegiatan proses pembelajaran, pengelolaan data siswa, baik itu nilai ujian dan lain-lain sebagainya yang berkaitan dengan proses akademik. Maka dari itu dapat kita simpulkan bahwa Sistem Informasi Manajemen akademik adalah suatu sistem kegiatan yang saling bekerja sama untuk menghasilkan sebuah informasi yang berguna dan dibutuhkan untuk demi kelancaran urusan akademis atau pendidikan.

Dalam penerapan Sistem Informasi Manajemen dimana manajemen sekolah atau perguruan tinggi masih perlu sangat diberi dukungan yaitu mulai dari sumber daya yang menggunakannya dan juga alat-alat yang diperlukan untuk dapat menunjang kegiatan sistem informasi manajemen tersebut. Tidak dapat dipungkiri bahwa dalam penerapan sistem informasi manajemen di sekolah atau perguruan tinggi masih terkendala oleh beberapa hal seperti jaringan komputer atau wi-fi, tenaga ahli yang sangat kurang memadai dan kurang cepatnya dalam mengupdate informasi atau data yang baru. Jika di dalam manajemen sekolah penerapan sistem informasi manajemen itu dipraktekkan dalam kegiatan akademik sekolah tersebut mulai dari pengelolaan data siswa sekolah, guru-guru, semua tenaga kependidikan dan staf-staf yang ada di sekolah tersebut.

Selain itu dalam manajemen sekolah sistem informasi manajemen nya sudah bersifat online dan juga offline. Untuk mengetahui berbagai data informasi yang dibutuhkan cukup membuka situs atau aplikasi tertentu yang dipakai oleh sekolah tersebut. Sistem informasi manajemen di sekolah juga sudah diterapkan dengan baik yaitu contohnya sudah beberapa tahun belakangan siswa sekolah menengah atas dan sederajat sudah melaksanakan ujian nasional berbasis komputer (UNBK),itu juga termasuk penerapan sistem informasi manajemen dalam manajemen sekolah. Dan dalam proses pembelajarannya sehari-hari sudah banyak juga sekolah yang menggunakan sistem informasi digital atau disebut juga dengan istilah belajar secara online atau daring untuk menggunakan suatu situs atau frekuensi tertentu di sekolah masing-masing.

Jadi tidak dapat dipungkiri bahwa penerapan sistem informasi manajemen di dalam manajemen sekolah sangat berperan penting karena akan mempermudah kegiatan atau pekerjaan di sekolah titik contohnya saja untuk mengakses soal-soal siswa bisa mencarinya di aplikasi atau situs 
yang sudah dikelola oleh sekolah tersebut. Begitu juga dengan masalah data-data sekolah untuk menyimpan data sudah secara online begitu juga untuk mencarinya kembali apabila dibutuhkan akan lebih cepat dan mudah lagi karena menggunakan sistem informasi manajemen yang baik dan teratur. Selain itu dalam manajemen sekolah penerapan sistem informasi manajemen yang baik akan mempermudah dalam pengambilan keputusan dan juga mempercepat pekerjaan bisa selesai tepat waktu dan akurat.

Pada perguruan tinggi penerapan sistem informasi manajemen sudah berjalan dengan cukup baik contohnya saja mahasiswa di perguruan tinggi untuk mengakses nilai dan informasi akademik lainnya cukup dengan membuka portal masing-masing mahasiswa. Sistem informasi manajemen di perguruan tinggi berbasis online apa saja data yang dibutuhkan mahasiswa bisa diakses dari situs atau aplikasi yang sudah disediakan pihak kampus perguruan tinggi titik penerapan sistem informasi manajemen dalam manajemen sekolah perguruan tinggi sangat memiliki peranan penting dimana semakin banyak pengelolaan sistem informasi manajemen tersebut maka segala pekerjaan yang dilakukan akan lebih cepat dan mudah titik untuk mengakses informasi atau data yang dibutuhkan akan lebih mudah dan cepat.

\section{D.Kesimpulan}

Sistem Informasi Manajemen merupakan suatu kesatuan sistem yang terdiri dari elemen dan komponen-komponen yang saling bekerja sama dan menghasilkan suatu informasi yang diperlukan bagi penggunanya tujuan utama dari Sistem Informasi Manajemen ini adalah untuk mempermudah pekerjaan apalagi yang berhubungan dengan data dan informasi. Manfaat dalam penerapan Sistem Informasi Manajemen (SIM) yaitu dapat meningkatkan efisiensi dan efektivitas data secara akurat dan tepat waktu, mempermudah pekerjaan manajemen mulai dari perencanaan pelaksanaan pengawasan dan lainnya, mampu meningkatkan kualitas sumber daya manusia dan dapat meningkatkan produktivitas serta penghematan biaya dalam organisasi. Penerapan sistem informasi manajemen dalam manajemen sekolah dan perguruan tinggi sangat memiliki peranan penting seperti mempermudah penyajian informasi dan mempercepat dalam pengambilan keputusan. Dan juga Sistem Informasi Manajemen sudah digunakan di berbagai sektor,dari sektor pendidikan contohnya Sekolah dan Perguruan Tinggi.

\section{DAFTAR PUSTAKA}

Dyna Marisa Khairina, D. (2018). Sistem Informasi Manajemen Ruang (Simeru)

Kelas (Studi Kasus: Fkti Universitas Mulawarman). Ilmiah Ilmu Komputer,

13(1),

3.

Retrieved

from

http://ejournals.unmul.ac.id/index.php/JIM/article /view/1023 
Indrayani, E. (2011). Pengelolaan Sistem Informasi Akademik Perguruan Tinggi

Berbasis Teknologi Informasi Dan Komunikasi (Tik). Penelitian Pendidikan,

12(1), $16 . \quad$ Retrievedfrom http://jurnal.upi.edu/file/5-

Etin_Indrayani.pdf

Lipursari, A. (2013). Peran Sistem Informasi Manajemen (Sim) Dalam Pengambilan

Keputusan. Stie $5(1)$, Semarang,

Retrievedfrom

http://jurnal3.stiesemarang.ac.id/index.php /jurnal/article/view/154

Shiddiq, S., \& Pradnya, W. M. (2013). Sistem Informasi Akademik Dan Administrasi Sdit Ar-Raihan Bantul. Ilmiah DASI, 14(4), 5. Retrievedfrom

https://ojs.amikom.ac.id/index.php/dasi/art icle/view/174

Triwiyanto, T. (2013). Pemetaan Mutu Manajemen Berbasis Sekolah Melalui Audit Manajemen Pendidikan. Manajemen Pendidikan, 24(2), 10. Retrievedfrom http://ap.fip.um.ac.id/wpcontent/uploads/2015/05/volume-24-no.234-43.pdf
Vindi Agustiandra, A. S. (2019). Persepsi Guru Terhadap Penerapan Sistem Informasi Manajemen Akademik Di Sekolah Menengah Kejuruan (Smk) Negeri 3 Padang. Bahasa Manajemen Pendidikan, 8(1), 8. Retrievedfrom

http://ejournal.unp.ac.id/index.php/bahana/ article/view/103704

\section{https://core.ac.uk > pdfPDF}

Hasil web

Manajemen Berbasis Sekolah (MBS): Konsep Dasar dan ...

Sabani, Ahmad titik Dewi Putri, A. (2019). Persepsi guru dalam meningkatkan mutu pendidikan berbasis sistem informasi manajemen di sekolah dasar negeri 08 batang Anai titik pendidikan, 1-6. Retrievedfrom

https://osf.io/w275f/download

Susanto, A.(2002). Pengaruh sistem informasi manajemen pendidikan dan kebutuhan informasi manajemen program sarjana reguler PTN terhadap informasi manajemen pendidikan titik pendidikan, 4(2),66-7. Retrievedfrom http://journal.unpad.ac.id/sosiohumaniora/ article/view/5260/2639

Creswell, J.W. (2018). Research Design: Qualitative,Quantitative, and Mixed Methods Approaches. Thousand Oaks, CA: SAGE Publication. 